\title{
The Influence of Advertising in Tiktok Social Media and Beauty Product Image on Consumer Purchase Decisions
}

\author{
Metta Darmatama ${ }^{1}$ Rezi Erdiansyah ${ }^{1 *}$ \\ ${ }^{1}$ Faculty of Communication, Universitas Tarumanagara, Jakarta 11440, Indonesia \\ "Corresponding author. Email: rezie@ fikom.untar.ac.id
}

\begin{abstract}
The use of TikTok's social media, which is increasingly popular with young people, has made marketers interested in advertising to market beauty products. However, the problem is that it is not easy to attract the attention of the audience to focus on one product on TikTok social media, adding that a less positive image of beauty products can result in the audience not making purchase decisions. The research objective was to determine the effect of advertisements on TikTok social media and the image of beauty products on consumer purchasing decisions. This research uses SOR theory, associative memory model, reasoned action theory, and AISAS model. The research methodology uses a quantitative approach and survey methods. The research sample was 96 people. Research data through questionnaires. The method of quantitative data analysis uses the multiple linear regression method. The results showed that advertising on TikTok social media and the image of beauty products together have a significant effect on consumer purchasing decisions. Product image provides the strongest influence on consumer purchasing decisions.
\end{abstract}

Keywords: brand loyalty, business communication, customer percieve value, sustainable fashion

\section{INTRODUCTION}

As the rapid growth of information and communication technology as well as the internet has driven the spread of large social networking sites in the last decade. Social media can be used as an advertising platform to create and strengthen bonds between business people and customers. Businesses use social media as a tool to advertise their products, which aims to convey marketing communication messages in order to attract attention and persuade online audiences. As many as $70 \%$ of consumers read online customer reviews before buying and $81 \%$ are influenced by peer social media posts [1].

Business people use social media to highlight the product's brand image because brand image plays an important role in determining marketing strategies and in changing future marketing. [2]. Brand image is a determinant that affects the subjective perceptions of customers which in turn consumers will evaluate a product before buying [3]. Currently, a large number of audiences are exposed to online advertising on social media but less product differentiation, adoption of shorter ad formats and an increase in the number of commercial times that repeatedly make it difficult for audiences to notice the advantages of a product advertised through social media [4].

The products advertised through TikTok social media are beauty products. The reason for the interest in beauty products is because based on the results of research conducted on 29 October to 8 November 2018 with 1,641 respondents and over 16 years of age, statistical data shows the percentage of female respondents in Indonesia who show that they are most interested in seeing beauty products, per November 2018 [5], It is known that lipstick products are the most popular beauty products favored by consumers who are endorsed by some of the celebrities, 70.4 percent of respondents said they were interested. In comparison, 9.3 percent of respondents said they were attracted to eyeshadow that was partially endorsed by celebrities.

Based on the background description above, the formulation of this research problem is as follows: (1) Is there a partial effect of advertising on TikTok social media on consumer purchasing decisions? (2) Is there a partial influence on the image of beauty products on consumer purchasing decisions? (3) Does advertising on TikTok social media and the image of beauty products jointly influence consumer purchasing decisions?

\section{THEORY}

The theory used in this research is the theory of SOR. The audience affected by online advertisements on TikTok social media will be processed in their minds, which are then responded well in the form of changes in buying behavior. The concept of advertising on social media is measured by two dimensions, namely (1) Social Media Ad Content; (2) social media sales promotion content [6]. Furthermore, the theory for the brand image variable uses the associative memory model [2] which can be explained as follows the 
associations that make a brand stand out in the minds of consumers. So, before consumers take a purchase decision, consumers will try to associate or relate something that consumers remember after being exposed to a stimulus from their online advertising. Brand image is measured in two dimensions, including: (1) brand functionality (usefulness of the brand); (2) symbolism (sense of status, fame, and recognition). Consumers who have a positive attitude towards brand image will certainly have an impact on the purchasing decision-making process [7].

Consumer purchasing decision making can be defined as a mental orientation that characterizes the consumer's approach to making choices [8]. This approach is concerned with cognitive and affective orientation in the decisionmaking process. Purchasing decisions made by consumers (consumer decision-making) is mental or behavioral, where cognitive elements are oriented to shopping related to their personality [9]. The theories used are the AISAS model (Attention, Interest, Search, Action and Share) and the AIDMA model (Attention, Interest, Desire, Memory, and Action), which are used to measure purchasing decision actions [10], which consists of the dimensions: (1) Attention, (2) Interest, (3) Desire, (4) Memory (keeping in memory), (5) Search, and (6) ) Action (action).

Based on the theoretical description presented, a framework of research can be described as shown in Figure 1.

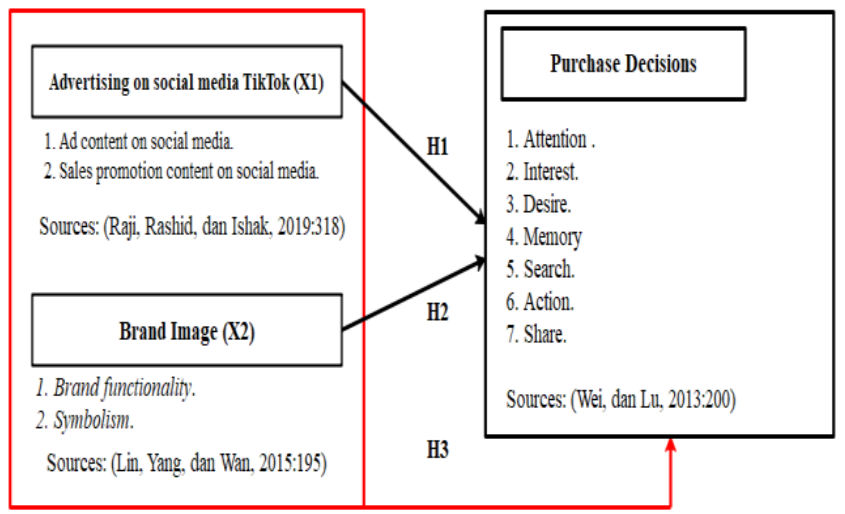

Figure 1 Research Framework

From Figure 1, regarding the framework of research, the following research hypothesis can be made:

H1 : There is a partial effect of advertising on TikTok social media on consumer purchasing decisions.

$\mathrm{H} 2$ : There is a partial influence on the image of beauty products on consumer purchasing decisions.

H3 : There is an effect of advertising on TikTok social media and the image of beauty products together on consumer purchasing decisions.

\section{METHODS}

This study uses a quantitative approach with survey research methods. The population as many as TikTok social media users has exceeded 100,000 people. So, the sampling technique used was purposive sampling which included the category of non-probability sampling. Based on calculations in the statistical table data belonging to [11] with a confidence level of $95 \%$ and an error rate of $10 \%$ obtained a sample of 96 people.

The research data was collected by distributing questionnaires. The research was analyzed quantitatively. The quantitative analysis method uses a simple multiple linear regression method. Furthermore, testing the validity of the study used the Pearson correlations formula. The research data is said to be valid if the calculated $\mathrm{R}$ value is greater than the $R$ table $(0.201$ for Sig. 0.05 and $n=96)$. Furthermore, the research data is declared reliable, if the results of the Cronbach's alpha value are greater than 0.7. Based on the results of the research validity test on the advertising variables on TikTok social media, product image, and purchase decisions indicate valid research data. Whereas in the results of the reliability test of each study, the Cronbach's alpha value of advertisements on TikTok social media was 0.886; while the product image obtained $\alpha=$ 0.896 ; and purchasing decisions obtained $\alpha=0.931$, which means that all research data is declared reliable or consistent in measuring the research variables.

\section{FINDINGS AND DISCUSSION}

\subsection{Partial-Test Results}

Based on the research data in the table above, the results of hypothesis testing can be answered through the following research data findings:

Ads on TikTok social media partially have a significant effect on consumer purchasing decisions, this is evidenced by the t-count value $(4,350)$ and the Sig. 0,000 . Because the Sig. $0.000<0.05$ or $<0.01$. Or it can also be seen from the acquisition of $t$ value $(4,350)>t$ table $(1.986)$ or $>t$ table $(2,627)$, thus it means that the hypothesis $(\mathrm{H} 1)$ is supported and accepted.

Image of beauty products partially has a significant effect on consumer purchasing decisions, this is evidenced by the acquisition of the t value (5.467) and the Sig. 0,000. Because the Sig. $0.000<0.05$ or $<0.01$. Or it can also be seen from the acquisition of t-value $(5,467)>t$-table $(1.986)$ or $>t$-table $(2,627)$ thus it means that the hypothesis $(\mathrm{H} 2)$ is supported and accepted. 
Table 1 Partial Test Results, Magnitude of Influence, ANOVA, Coefficient of Determination

\begin{tabular}{|c|c|c|c|c|c|c|c|}
\hline \multirow[b]{2}{*}{ Model } & \multicolumn{2}{|c|}{$\begin{array}{l}\text { Unstandardized } \\
\text { Coefficients }\end{array}$} & \multirow{2}{*}{$\begin{array}{c}\begin{array}{c}\text { Standardized } \\
\text { Coefficients }\end{array} \\
\text { Beta }\end{array}$} & \multirow[b]{2}{*}{$t$} & \multirow[b]{2}{*}{ Sig. } & \multicolumn{2}{|c|}{$\mathrm{t}_{\text {tabel }(\mathrm{n}=94)}$} \\
\hline & B & Std. Error & & & & $\begin{array}{l}\text { Sig. } \\
0,05 \\
\end{array}$ & $\begin{array}{l}\text { Sig. } \\
0,01 \\
\end{array}$ \\
\hline 1 (Constant) & 8.183 & 3.943 & & 2.076 & .041 & & \\
\hline $\begin{array}{l}\text { Advertising on } \\
\text { social media } \\
\text { TikTok }\end{array}$ & .733 & .169 & 411 & 4.350 & .000 & 1,986 & 2,627 \\
\hline $\begin{array}{l}\text { Image of beauty } \\
\text { products }\end{array}$ & .908 & .166 & .516 & 5.467 & .000 & & \\
\hline & & & & $\mathrm{F}$ & Sig. & $\mathrm{F}_{\mathrm{t}}$ & bel \\
\hline ANOVA & & & & 192.153 & $.000^{\mathrm{b}}$ & 3,094 & 4,841 \\
\hline $\mathrm{R}$ square & & & & 0,805 & & & \\
\hline
\end{tabular}

a. Dependent Variable: Consumer purchasing decisions

\subsection{Beta-Coefficient Test $(\beta)$}

Based on the results of the research data findings in the table above, it can be seen clearly the magnitude of the influence by looking at the results in the standardized coefficients beta column, as follows:

The magnitude of the influence of advertisements on TikTok social media on consumer purchasing decisions is obtained by the value of standardized coefficients beta, namely 0.411 , which is based on standardized coefficient interpretation guidelines showing that $\beta=0.411$ is greater than $(>) 0.25$, which means that there is a strong influence [12].

The magnitude of the influence of the image of beauty products on consumer purchasing decisions is obtained by the value of standardized coefficients beta, namely 0.516 , which is based on the standardized coefficient interpretation guidelines, indicating that $\beta=0.516$ is greater than $(>) 0.25$, which means that there is a strong influence. [12].

\subsection{ANOVA}

ANOVA test results (simultaneous test), it can be seen clearly that the results of the simultaneous effect of advertising on TikTok social media and the image of beauty products on consumer purchasing decisions', the Fcount is 192.153 and Sig. 0,000. Due to the Sig. $0.000<0.05$ or it can also be seen from the acquisition of Fcount (192.153)> Ftable (3.094) and > Ftable (4.841), thus it can be said that the hypothesis (H3) is accepted, which states that there is an effect of advertising on TikTok social media and the image of beauty products collectively on consumer purchasing decisions.

\subsection{Coefficient-of-Determination Test}

The percentage of consumer purchasing decisions after being influenced by advertisements on TikTok social media and the image of beauty products obtained by the $\mathrm{R}$ square value is 0.805 converted into a percentage of $0.805 \times 100 \%=$ $80.5 \%$ and the remaining $100 \%-80.5 \%=19.5 \%$ is determined by Other variables that were not studied were service quality, sales promotion, and Vloger or celebrity endorser variables.

\subsection{Discussion}

Based on the results of hypothesis testing, the research discussion can be described in order to answer the research objectives as follows:

The results show that advertisements on TikTok social media partially have a significant effect on consumer purchasing decisions, and the magnitude of the influence is obtained $\beta=$ 0.411 including the category of strong influence.

The findings of this study are in line with previous studies, It was found that online advertising, which is generally seen via Smartphone cellphones, has a significant effect on consumer purchase intentions [13]. The results of this study are in accordance with the theoretical use of SOR, namely online advertising provides stimulation to audiences who open the TikTok social media application, then online advertising messages about beauty products are processed in the minds of the audience according to their level of knowledge, which in turn influences the behavior to decide. the act of purchasing beauty products.

This is in line with what was stated [14] states that consumer knowledge about the product is an individual characteristic that is proven to have an effect on the purchasing process.

The results showed that advertisements for beauty products on TikTok social media have a positive and significant effect 
on consumer purchasing decisions because the dimensions of beauty product advertisements which include advertising content and sales promotion content attract the attention of online audiences. The audience assessed that the content of beauty product advertisements on TikTok social media looked creative, the message information conveyed was considered credible and had useful / useful value, then beauty product advertisements offered the latest advantages. The content of beauty product advertising messages on TikTok social media that are relevant to consumer needs can influence the purchase decision action because the advertising message is effective in shaping consumer positive attitudes towards the product. This is supported by a statement states that relevant messages will be accepted as an important factor related to the effectiveness of digital advertising. So, digital advertising can be said to be effective and successful when the message it sends is relevant to consumer needs. Furthermore, what makes consumers take purchasing decisions is because beauty product advertisements display sales promo content / messages [15] In research states that promotion has a significant effect on purchasing decisions on a brand in the market [16].

Electronic messages also have an important role to play in improving consumer purchasing decisions. Electronic messages in the form of sales promotions, such as giving discounts, available gifts, and lowering product prices.

The results show that the image of beauty products partially has a significant effect on consumer purchasing decisions, and the magnitude of the influence is obtained $\beta=0.516$ including the category of the strongest influence.

The findings of this study are in line with previous research, which states that brand image partially has a significant effect on purchasing decisions for Maybelline Make-Up products [17].

The results of this study are in accordance with the proposed theoretical use of the associative memory model [2].

The results of this study indicate that the image of beauty products partially has a significant effect on consumer purchasing decisions, meaning that the more the brand image of a beauty product is enhanced, the purchase decision will increase. The concept of brand image that influences consumers to make purchasing decisions includes two dimensions, namely brand functionality (usefulness of the brand) and symbolism. Judging from the brand functionality, it shows that this $\mathrm{X}$ brand beauty product is indeed of high quality, comfortable to use for skin and has better characteristics than its competitors so that consumers are interested in making a purchase decision. Thus, it can be said that brand image serves as an information signal that buyers use to form conclusions about the quality of merchandise [18]. Furthermore, seen from the symbolic dimension, it shows that the $\mathrm{X}$ brand beauty product has a different personality from its competitors, added again that this $\mathrm{X}$ brand is one of the best brands in beauty cosmetic products, then if consumers use the $\mathrm{X}$ brand it will get a positive assessment from others and received praise from his playmates.

The results show that there is a simultaneous effect of advertising on TikTok social media and the image of beauty products on consumer purchasing decisions, which is significant, and the magnitude of the influence is obtained $\beta$ $=0.897$ including the very strong influence category.

The results of the research findings are in line with the purchase decision theory, which states that purchasing decisions are patterns of consumer behavior that determine and follow a decision process consisting of various stages to achieve a choice [14].

The same thing is in accordance with the explanation of the AISAS model, namely the process of purchasing decisions for a product begins with attention, consumers who pay attention to the product and have a positive attitude will generate interest in the product, then search for information related to the product, which in in turn make an action (action) in the form of a purchase decision, and have the opportunity to share product advertising content that has given him satisfaction.

\section{CONCLUSION}

Based on the results of hypothesis testing and research discussion, the conclusions of this study can be described as follows: (1) advertising on TikTok social media partially has a strong and significant effect on consumer purchasing decisions, meaning that beauty product advertisements on TikTok social media are increasingly being enhanced by paying attention to the dimensions -dimensions: advertising content (such as credible information, creative content, offering something new) and sales promotion content such as offering discounts, giving gifts, lowering product prices) will further enhance consumer purchasing decisions. (2) The image of beauty products partially has a strong and significant effect on consumer purchasing decisions, meaning that the image of beauty products is increasingly enhanced in the dimensions of brand functionality (usefulness of the brand) such as high product quality, having a different uniqueness from competitors, resulting in a product performance is better, and comfortable to use for skin and symbolism such as making consumers 'personalities look different from competitors, is the best brand in the cosmetics sector, using the best brands makes consumers accepted in the circle of friends, brand X does not disappoint and can improve consumers' social status so that This beauty brand is desired by consumers. (3) Advertising on TikTok social media and the image of beauty products together have a significant effect on consumer purchasing decisions. From the research findings, it turns out that the most powerful and significant variable influencing consumer purchasing decisions is the image of beauty products.

\section{REFERENCES}

[1] Muñoz, C. L. and Wood, N. T. 2015. Update Status: The State of Social Media Marketing Curriculum. Journal of Marketing Education, 37 (2), 88-103.

[2] Mitra, S. and Jenamani, M. 2020. OBIM: A computational model to estimate brand image from online 
consumer review. Journal of Business Research, 114), $213-226$.

[3] Lien, C.-H., Wen, M.-J., Huang, L.-C. and Wu, K.-L. 2015. Online hotel booking: The effects of brand image, price, trust and value on purchase intentions. Asia Pacific Management Review, 20), 210-218.

[4] Vashisht, D. and S., S. 2015. Effects of brand placement strength, prior game playing experience and game involvement on brand recall in advergames. Journal of Indian Business Research, 7 (3), 292-312.

[5] Hirschmann, R. 2018. Share of respondents who indicated they were most interested to see the following beauty products as part of a collaboration with a celebrity, as of November 2018. Statista, City.

[6] Raji, R. A., Rashid, S. and Ishak, S. 2019. The mediating effect of brand image on the relationships between social media advertising content, sales promotion content and behaviuoral intention. Journal of Research in Interactive Marketing, 13 (3), 302-330.

[7] Lin, M. L., Yang, J.-T. and Wan, C.-S. 2015. Effect of restaurant discount coupon depth on re-consumption willingness: A moderating role of brand image. Tourism and Hospitality Research, 15 (3), 193-205.

[8] Silayoi, P. and Speece, M. 2004. Packaging and purchase decisions. British Food Journal, 106 (8), 607628 .

[9] Goswami, S. and Khan, S. 2016. Impact of Consumer Decision-making Styles on Online Apparel Consumption in India. Vision: The Journal of Business Perspective, 19 (4), 303-311.

[10] Wei, P.-S. and Lu, H.-P. 2013. An examination of the celebrity endorsements and online customer reviews influence female consumers' shopping behavior. Computers in Human Behavior, 29), 193-201.

[11] Rea, L. M. and Parker, R. A. 2014.Designing and Conducting Survey Research : A Comprehensive Guide. John Wiley \& Sons, Incorporated, Somerset, UNITED STATES.

[12] Keith, T. Z. 2015.Multiple Regression and Beyond An Introduction to Multiple Regression and Structural Equation Modeling. Routledge, New York.

[13] Martinsa, J., Costab, C., Oliveirab, T., Gonçalvesa, R. and Brancoa, F. 2018. How smartphone advertising influences consumers' purchase intention. Journal of Business Research), 1-10.
[14] Karimi, S., Papamichail, K. N. and Holland, C. P. 2015. The effect of prior knowledge and decision-making style on the online purchase decision-making process: A typology of consumer shopping behaviour. Decision Support Systems, 77), 137-147.

[15] Taylor, C. R. 2009. The Six Principles of Digital Advertising. International Journal of Advertising, 28 (3), $411-418$.

[16] Reza Jalilvand, M. and Samiei, N. 2012. The effect of electronic word of mouth on brand image and purchase intention. Marketing Intelligence \& Planning, 30 (4), $460-476$.

[17] Savitri, S. A. and Erdiansyah, R. 2019. Pengaruh Citra, Kredibilitas dan Kemampuan Komunikasi Beauty Vlogger Terhadap Keputusan Pembelian Produk MakeUp Maybelline (Studi Kasus Tasya Farasya). Prologia, 3 (1), 267-273.

[18] Porter, S. S. and Claycomb, C. 1997. The influence of brand recognition on retail store image. Journal of Product \& Brand Management, 6 (6), 373-387. 